\title{
Stakeholder Perspective of Handling the Deceased during the Nipah Virus Outbreak in Kerala, South India, 2018
}

\author{
Prajitha Kannamkottapilly Chandrasekharan, ${ }^{1 \star}$ Arya Rahul, ${ }^{1}$ Ramachandran Nair Saraswathy Gopakumar, ${ }^{2}$ and \\ Anish Thekkumkara Surendran Nair ${ }^{3}$ \\ ${ }^{1}$ Department of Community Medicine, Government Medical College, Thiruvananthapuram, India; ${ }^{2}$ Health Officer, Municipal Corporation, \\ Kozhikode, India; ${ }^{3}$ Department of Community Medicine, Government Medical College, Thiruvananthapuram, India
}

\begin{abstract}
In any outbreak situation, a poor stakeholder response can impede the outbreak control and can have high economic and social cost. We conducted a qualitative study to understand stakeholder response in handling of the Nipah deceased persons during the outbreak of Nipah in Kerala, 2018. To understand the responses and to generate knowledge from the data, we used grounded theory approach for the study and conducted in-depth interviews and focus group discussion. Mixed public response and swift state response emerged as the main themes in our study. Under the "mixed public response," three categories emerged, including anxiety and fear, conflicting religious beliefs, and humanitarian concern. Under the "swift state response," the categories emerged were critical resources and robust guidance. A collective effort involving the administration, local and religious groups, and a culturally acceptable scientific protocol proved to be good examples of gaining social acceptance. Kerala puts forth a model of efficient community engagement and communication to gain public support and acceptance in a fatal disease outbreak.
\end{abstract}

\section{INTRODUCTION}

In May 2018, Kerala experienced an outbreak of Nipah virus, a deadly viral encephalitic fever which the state has never seen before. The outbreak began with a 28-year-old man who presented with encephalitis to a private facility in Kozhikode District, Kerala. On the same day, his father and aunt developed fever and myalgia. His brother had died 12 days back with similar symptoms. Nipah claimed 16 lives among the 18 laboratory-confirmed cases in Kozhikode and Malapuram districts of Kerala, with a case fatality rate of $88.8 \% \cdot{ }^{1-4}$ Around 3,000 persons were kept in home quarantine during the time period for 21-42 days. ${ }^{4,5}$ The WHO appreciated the efficient handling of the situation by Kerala's health system that detected and contained the virus before it could escalate to a more widespread epidemic. ${ }^{6}$ But the path of this effective containment was filled with unprecedented hurdles.

When people experience a novel fatal pathogen, they exhibit a variety of behaviors from anxiety to resisting the medical services. As the disease progresses, symptoms worsen and the chance of infectivity is more around the last days of the patient. ${ }^{7,8}$ The dead bodies can also act as a potent source of infection, and in this context, its handling become an important step in outbreak control. ${ }^{9}$ The religious sentiments associated with funeral procedures further increases the intricacy of the issue. It becomes a collective responsibility of the government and health system to ensure dignity and safety in funeral procedures without hurting religious sentiments. A poor stakeholder response can impede the outbreak control and can have high economic and social cost. ${ }^{10}$ At this juncture, it is important to understand their perspective in this issue to inform future Nipah intervention strategies. The aim of our study was to explore and understand stakeholder response in handling of the Nipah deceased during the outbreak of Nipah in Kerala, 2018.

\footnotetext{
*Address correspondence to Prajitha Kannamkottapilly Chandrasekharan, Department of Community Medicine, Government Medical College, Thiruvananthapuram 695011, India. E-mail: drprajithacpillai@ gmail.com
}

\section{METHODOLOGY}

The present qualitative research was undertaken in Kozhikode District of Kerala, India, during December 2018February 2019. Kerala's 14 revenue districts are divided into municipal corporations (Kozhikode corporation is one among them), municipalities, and grama panchayaths. The three main religions in the state include Hinduism, Islam, and Christianity. All religions give funeral a sacred significance, and funeral rites and rituals in the state are usually guided by the respective religion. According to Kerala Municipality Act, 1994, the concerned local body secretary/health officer is the responsible person to dispose the dead bodies of the destitute and deaths due to communicable diseases. ${ }^{11}$

To understand the responses and to generate knowledge from the data, we used grounded theory approach for the study and conducted in-depth interviews and focus group discussion. Participants were chosen purposively based on their involvement in handling the Nipah dead bodies as obtained from official records (Table 1). In-depth interviews of a district official who was assigned with the responsibility of cremation of Nipah viral deaths, people's representative under whose constituency the Kannamparambu mosque is located and where deep burials were conducted, a religious leader, an individual from a dedicated team who helped in the cremation processes, and a member of state rapid response team involved in the containment of Nipah outbreak were done. A focused group discussion was conducted with corporation health workers, including the health inspector, junior health inspectors, ambulance drivers, and sanitation workers. Each participant was contacted over phone, and the study objective was informed and willingness enquired. Once verbal consent was obtained, date, time, and place for one-to-one interview were fixed according to the convenience of the interviewee. Interview with the district official, religious leader, and staff member of dedicated team for cremation was conducted at the Kozhikode corporation office.

Interview with people's representative was conducted at his office. One-to-one interview with the member of state rapid response team was conducted at Government Medical College, Thiruvananthapuram. Interviews lasted on an average of 
1 hour, ranging between 40 minutes and 1 hour 30 minutes. Focus group discussion was conducted at the corporation health office and lasted for 1 hour 50 minutes.

The interviews were done with topic guide and were participant led (Table 2). All interviews were conducted maintaining the confidentiality, after obtaining the informed consent, and were audio recorded. The recordings were transcribed and translated to English. Thematic analysis using hybrid coding process was the approach followed. Data were coded manually and were rigorously reviewed and categorized. The emerging patterns, themes, and relationships were identified. Consensus on emerging themes was reached through regular discussion. Direct quotes were used wherever possible to highlight the themes identified. Ethical clearance was granted by the Institution Ethics committee, Government Medical College, Thiruvananthapuram.

\section{RESULTS}

Under the guidance of the government, 12 funerals were conducted from May 22, 2018 to June 6, 2018. Among these, 10 bodies were cremated and two bodies were buried (Table 3).

Data analysis led to the emergence of 30 codes and two main themes: "mixed public response" and "swift state response." Under the "mixed public response," three categories emerged: anxiety and fear, conflicting religious beliefs, and humanitarian concern. Under the "swift state response," two categories emerged: critical resources and robust guidance.

Mixed public response. The public response to the exotic virus was a mixture of fear, anger, conflicting ideas, responsibility, and humanitarian concerns.

Anxiety and fear. The "new disease" initially brought in suspicion and mistrust. The news of Nipah deaths that appeared in newspaper headlines induced a state of "fear psychosis" among the public. Death became a part of the outbreak and, thus, the handling of dead bodies. It was on May 22, 2018, the decision was made to conduct cremation processes of all Nipah deaths at Kozhikode itself under the guidance of government rather than sending the bodies to their native places.

Initial days saw a widespread lack of public knowledge and this in turn multiplied the uncertainty regarding the disease. Many rumors that circulated further lead to the spread of suspicion. It was when the Chalathara crematorium was approached because of blower breakdown at the Kozhikode electric crematorium that the unfortunate fear-induced response was initially heard.

The response from their part was very indifferent. They said 'bad' people who died of some diseases can't be cremated here. It will result in harmful smoke being generated and will affect the healthy people like us. (District official)

The panic associated with the spread of this virus was so huge that they repeated their reluctance to every official even after ensuring all possible personal protective measures. They even denied the request for evacuating a platform so that the health staff themselves can do the cremation procedures. Burner repair got delayed because of the fear-instilled reluctance from the part of technicians to travel to Kozhikode.
TABLE 1

List of people interviewed

\begin{tabular}{ll}
\hline \multicolumn{1}{c}{ Type } & \multicolumn{1}{c}{ People involved } \\
\hline In-depth interview & People representative \\
& District official \\
& Religious leader \\
& Staff of dedicated team for cremation \\
Focus group discussion & One health inspector \\
& Two junior health inspectors \\
& Two ambulance drivers \\
& Two sanitation workers \\
\hline
\end{tabular}

Fear of death was definitely present. But when we saw our superior officers fearlessly toiling day and night, we had no time for a second thought. (Sanitation worker 2)

A cultural practice deep rooted in the state was that the best way of showing concern for a sick or hospitalized person is visiting him. The same was the practice in the event of a death. Distancing, hence, was a very difficult task. The scenario turned around after the burial of the father of the index case.

. . at that time we constantly kept asking them to keep a distance, but they were not obeying. We ourselves had to control them and keep them at a distance. The next day the 'famous image' appeared in newspapers which showed the four pallbearers along with the ambulance driver, ... and myself, with all the personal protective equipment. And from then a fear psychosis spread in the district and the city became deserted. People wore a mask even when they were driving inside a vehicle. (District official)

The media initially was very critical and tried to exaggerate things. Some false information created widespread public panic. But later days of the outbreak saw a fully supportive and matured behaviour from the media. (Junior health inspector 2)

The fear wave in the state grew to such an extent that some bereaved shied away from handling the bodies of the departed. Life was precious for everyone and fear was palpable everywhere.

Conflicting religious beliefs. Although the guidelines were formulated in line with known and available information, it came into being that not much attention was given to the cultural implications of communities of some affected individuals initially. The practice of cremation is in direct conflict with the widely held views of life after death and, hence, was forbidden in certain communities. This lead to a wave of conflict opposing cremation.

They said they won't allow cremation whatever happens and the body should be buried according to their religious beliefs. They created lot of trouble. Hours were lost on this issue and at last a new standard operating procedure was prepared. (District official)

There was constant discussion of administration with local and religious leaders, and finally, the decision was taken that burial under the special conditions can be done in Kozhikode itself without the bodies being carried to the home town. 
The challenge was to bring things into a consensus. 'Imam' of kannanparambu was given the option of deep burial and if not accepted they had to agree for cremation. They had no choices left. The respected religious leader Mr........ was called and extended his support. (People's representative)

Once an option for burial is available without compromising the religious beliefs, there was no reason for a denial.

Kannanparambu crematorium has a history of social commitment which goes back to the 1860s Cholera outbreak. The crematorium has been pledged for social support and we have no option to resist a burial on the grounds of a disease. (Religious leader)

The success of the scenario lied in the fact that the religious leaders could consider scientific facts and humanitarian values above their religious sentiments in the crucial situation.

Humanitarian concerns. As panic gripped Kozhikode, the place known for its compassion at times turned hostile. When the crematorium staff resisted offering services, a dedicated group of people who offer cremation services came for rescue.

...It was in this search we heard that people from . . used to visit homes and conduct cremation. We then contacted them and asked if they could help us in cremation of people who died of this disease. They agreed immediately. (District official)

When media started reporting their involvement, they faced some discrimination from the public.

... even though they considered us the 'Nipah dead body burning people' and showed a bit of indifferent attitude in public places, we consider it a privilege to be a part of this great activity. (A staff from dedicated team for cremation)

The health staff, ambulance drivers who helped in transport of the dead bodies, and sanitation workers had all put humanity in front of fear. Their foremost concern was to prevent the spread of infection to others. Many of them stopped using public transport, shifted to hotel rooms, and distanced themselves from their family and kids.

In one way or the other, most people here are social activists. Apart from literacy, compassion and social obligation helped a great deal in convincing people. (People's representative)

Swift state response. Robust guidance. An extraordinary swift decision-making from the state healthcare machinery was evident in all aspects of outbreak containment. In an effort to reduce the spread of infection during the funeral practices, an order was released by the district collector to conduct cremation processes of all Nipah deaths at Kozhikode itself under the guidance of the government and the electric crematorium in Kozhikode Corporation was devoted for the purpose. The responsibility for cremation was entrusted to a nodal officer and staff for his assistance.
It all started when the Kozhikode Mayor called me and asked me to resolve an issue in Chalathara crematorium. When I went there, workers were refusing to cremate the bodies of two Nipah victims in the fear of getting infection. I tried explaining and ensured all necessary protection but they continued to oppose. (District official)

Issues totally turned when a 55-year-old person from Muslim community (father of the index case) died of Nipah. As a result, a proposition was made in consultation with prominent religious and political leaders to modify rituals to levels that are culturally acceptable and are effective in preventing the spread of disease. A new standard operating procedure was prepared by the National Centre for Disease Control (NCDC).

We were given training to handle the dead bodies. Dr... from NIV, who had field level experience with Ebola victims at places like Angola was also present and gave hands on training with personal protective equipment and disinfection. Besides, every funeral was preceded by a training session lasting for about 1 hour for every-one involved. (District official)

We have insisted that NCDC guidelines should be observed even in cremation of all Nipah suspected cases. The safety of people involved in handling of dead bodies was one of our major concern. Their list was prepared and was constantly monitored for development of any signs and symptoms. (Member of state rapid response team)

As per the protocol, there should be no water bodies near a burial, and the pit should be 10-feet deep. The team had instructions to remove all jewelry, mobile phones, and other material and wear personal protective gear, goggles, and two layers of gloves while handling the body. The body was sealed in airtight bags and buried after adding $5 \mathrm{~kg}$ of bleaching powder into the burial pit. After placing the body, it was covered with $5 \mathrm{~kg}$ of bleaching powder again and filled with sand. Afterward, the gowns used by people involved in the cremation were decontaminated before removal and were disinfected.

Critical resources. The unprecedented attack of this deadly virus challenged the health system with an obvious deficiency of human and material resources. The relatives started showing reluctance to accompany the health staff for funeral process. There was a definite shortage of human resources and the existing workforce had to work round the clock.

We had to do everything from being pallbearers to saying the funeral rites. It was sad to see that none of the family members were willing to do the rituals. Everybody was scared. (District official)

At the same time, there were shortage of bags and plastics to seal the body. The resource shortage was tackled by accepting external help. Health minister directly got involved and made immediate arrangements for procuring body bags, N95 mask, and personal protective equipment kits. The shortage in human resources was tackled by temporary appointments and accepting help from volunteers. 
TABLE 2

Interview schedule

\begin{tabular}{|c|c|c|c|}
\hline Topic & Main question & Follow-up question & Probe question \\
\hline $\begin{array}{l}\text { Handling death and deceased } \\
\text { during Nipah outbreak }\end{array}$ & $\begin{array}{l}\text { What was the response from the } \\
\text { public }\end{array}$ & $\begin{array}{l}\text { How did public react toward } \\
\text { government decisions }\end{array}$ & $\begin{array}{l}\text { What happened with passage of } \\
\text { time }\end{array}$ \\
\hline Health system response & $\begin{array}{l}\text { What were the actions/guidance } \\
\text { from the part of the health system }\end{array}$ & $\begin{array}{l}\text { What were the main challenges in } \\
\text { implementing government } \\
\text { decisions }\end{array}$ & $\begin{array}{l}\text { How did the government respond } \\
\text { to the challenges }\end{array}$ \\
\hline Humanitarian aspect & $\begin{array}{l}\text { Who were the people who } \\
\text { supported the activities }\end{array}$ & $\begin{array}{l}\text { What where the challenges faced } \\
\text { by them }\end{array}$ & How did they overcome it \\
\hline Lessons learned & $\begin{array}{l}\text { What were the main lessons } \\
\text { learned }\end{array}$ & $\begin{array}{l}\text { How can these guide future } \\
\text { outbreak responses }\end{array}$ & - \\
\hline
\end{tabular}

\begin{abstract}
.... Ribavarin was made available for patients and Mab was arranged from Queensland, Australia. (member of state rapid response team)
\end{abstract}

\section{DISCUSSION}

Our interaction with the stakeholders involved in handling the Nipah decedents highlighted how the public response evolved from fear to empathy and the efficient guidance from the government in handling the outbreak with limited resources. Fear-related behaviors play an important role in shaping any disease outbreak. ${ }^{7}$ Stress and fear reactions in response to infectious disease are considered normal and potentially adaptive or protective. ${ }^{12}$ With the introduction of a novel virus, fear and anxiety were profound among the public. As in any other community, a lack of robust knowledge regarding the disease and the rumors associated with the disease transmission was a corner stone in spreading the unnecessary fear and confusions. The evidence of transmission of highly infectious disease from the deceased to healthy individuals exists from outbreaks of diseases such as Ebola, Lassa fever, and the disease caused by Neisseria meningitidis. ${ }^{13,14}$ A study from Guinea during Ebola outbreak of 2014-2015 reported that 85 confirmed cases were linked to one traditional funeral ceremony. ${ }^{14}$ During the 2014 Ebola outbreak in Liberia, $8.9 \%$ of confirmed cases were associated with funerals. ${ }^{15}$ Few evidences of occasional NiV transmission from corpse to healthy individuals exist from Bangladesh Nipah outbreak, 2010. ${ }^{16}$

From the initial days of Nipah outbreak in Kerala, there were suspicions of disease transmission from the corpse of the index case. ${ }^{1}$ Thus, death was closely related to fear and apprehension among the public. However, there were significant

TABLE 3

Funerals conducted under government guidance

\begin{tabular}{cllcl}
\hline Confirmed/suspected & Gender & Religion & Date of funeral process & Funeral process \\
\hline Confirmed & Male & Hindu & May 22, 2018 & Cremation \\
Confirmed & Male & Hindu & May 22, 2018 & Cremation \\
Confirmed & Male & Muslim & May 23, 2018 & Deep burial \\
Confirmed & Female & Hindu & May 26, 2018 & Cremation \\
Suspected & Male & Hindu & May 26, 2018 & Cremation \\
Confirmed & Male & Hindu & May 27, 2018 & Cremation \\
Suspected & Female & Muslim & May 27, 2018 & Deep burial \\
Confirmed & Male & Hindu & May 30, 2018 & Cremation \\
Confirmed & Male & Hindu & May 31, 2018 & Cremation \\
Confirmed & Male & Hindu & June 01, 2018 & Cremation \\
Suspected & Female & Hindu & June 02, 2018 & Cremation \\
Suspected & Male & Hindu & June 03, 2018 & Cremation \\
\hline
\end{tabular}

differences in the fear-induced responses across different nations. During the Ebola outbreak in Africa, fear of cremation, stigma, and having the family placed in quarantine lead to harmful behaviors from the public such as accusing health workers, hiding cases and deaths, conducting secret burials, and producing false death certificates. ${ }^{7,8,17}$ The anxious behavior seen in Kerala had a doubtful advantage. Our results showed an initial fear-induced defiance faced by the administration during cremation in the form of noncooperation and denial of space. This later showed favorable effects in social distancing and self-reporting. Fearless attitude and constant support from the higher officials were instrumental in uprooting fear and sustaining motivation among the health workers.

Funeral process in any community is inevitably linked with the religious beliefs and sentiments. Resistance was faced by the officials from public wherever a prescribed scientific protocol was implemented in the funeral processes. The story of Ebola outbreaks in West Africa put forth evidence of incompatibility between some religious and cultural practices and prescribed scientific methods. Practices of washing and cleansing the corpse, "'love touch," laying over the corpse and many such burial rituals were an important cause of spread of the disease in Ebola outbreaks of Africa. The issue was further worsened by the gross unawareness that existed among the public about the disease. The government protocol for cremation created suspicion and discontentment among the affected communities and led to harmful practices. ${ }^{17}$ Nipah outbreaks in Bangladesh saw a similar lack of community trust in the public healthcare system evident from the community residents blaming hospital doctors for patient deaths and rejecting biomedical explanation for Nipah transmission. ${ }^{18}$ Close handling of dead bodies, including cleansing the orifices immediately after death and burials denying health system advices was widely prevalent in the history. 9,16

Kerala is a land of diversity in religion and culture, and all religions give funeral a sacred significance. Funeral was considered an important step in transformation from the world of the living to the spiritual world, be it reincarnation of soul as in Hindu philosophy or a life after death in another world as believed by Muslims and Christians. Bathing the dead body is a practice prevalent in many communities and this can be a cause of direct spread of infection as secretions from a deceased person are considered equally infectious as that of a living infected person. ${ }^{19,20}$ To prevent such avoidable disease transmission, decision was taken by the government to conduct cremation at Kozhikode itself. Addressing the funeral issue was an important concern for the government for containing the outbreak where religious beliefs hold an upper hand in funeral 
customs. This led to agitations among certain communities against the government order of cremation of all Nipah deaths. The situation was efficiently managed by effective scientific communication between the government, religious, local leaders, and the public that resulted in a culturally acceptable and scientifically sound protocol for funeral procedures.

Highly infectious diseases put forth the workers handling the deceased at the risk of infection through body fluids or secretions. ${ }^{21-23}$ Our study shows that in spite of this knowledge of potential transmission, many people, including drivers, helpers for cremation, and sanitation workers, came forward. Health workers worked almost without a break, thereby preventing a further wave of transmission. ${ }^{6}$ Their perception of readiness was the victory of humanitarian concern over fear.

Apart from fear and cultural conflicts, there were unforeseen obstacles in the form of blower breakdown in the electric crematorium, difficulty in finding alternate places for cremation or burial in the densely populated city of Kozhikode and shortage of material and human resources. Outbreak of a highly infectious disease demands mobilization of extra resources apart from the regular healthcare machinery in the state. ${ }^{24}$ The shortage of human and material resources for handling the human remains came over the existing lack of resources in surveillance, isolation, and infection control during the outbreak. The vigilant health system tackled the paucity in resources on time. Al though the initial response in the community included fear and stigma, the literacy and scientific priming of the community enabled better communications and acceptance of the situation.

Reports show how the Ebola outbreak in Liberia, 2014, devastated the country's already fragile health systems and its unpreparedness to efficiently respond to initial cases and deaths. ${ }^{25,26}$ Role of health system of the country in controlling public health threats at the earliest as an important measure of global health security is well documented. ${ }^{27}$ In many developed nations, dedicated organizations and businesses are affiliated with funeral industry and handling of human remains. ${ }^{22}$ Immediately after the confirmation of the outbreak, the health system of Kerala was keen in ensuring safe and dignified burial for the decedents. Support from CDC and other partners was instrumental in capacity building and rapid comprehensive response. The sincere effort of media in transparent reporting and disseminating health information aided the government in communicating with the people and dealing with their uncertainties. In the journey through the cremation processes, at times, the system became a better care taker than the family.

\section{CONCLUSION}

Every public health threat comes with a hidden opportunity to device global innovative solutions for future outbreaks. Education and scientific priming of the community is the backbone of any epidemic control; evident from the social response during the Kerala Nipah outbreak. A collective effort involving the administration, local and religious groups, and a culturally acceptable scientific protocol proved to be good examples of gaining social acceptance. Kerala puts forth a model of efficient community engagement and communication to gain public support and acceptance in a fatal disease outbreak.

\section{LIMITATIONS}

The main limitation of our study is that we did not capture the community perspective which might have yielded the other side perspective. In-depth interviews of state and district officials might have prompted a positive bias highlighting the efficiency of the government and health system. Every effort was made to avoid such bias through probing questions ensuring communication in all dimensions.

Received February 28, 2020. Accepted for publication May 23, 2020.

Published online June 22, 2020.

Acknowledgments: We thank Indu P. S., Head of Department of Community Medicine, Government Medical College, Thiruvananthapuram, for assistance with the methodology and for comments that greatly improved the manuscript. The American Society of Tropical Medicine and Hygiene (ASTMH) assisted with publication expenses.

Author's addresses: Prajitha Kannamkottapilly Chandrasekharan, Arya Rahul, and Anish Thekkumkara Surendran Nair, Department of Community Medicine, Government Medical College, Thiruvananthapuram, India, E-mail: drprajithacpillai@gmail.com, aryaasp@gmail.com, and doctrinets@gmail.com. Ramachandran Nair Saraswathy Gopakumar, Kozhikode Corporation, Kozhikode, India, E-mail: gopakumar7@ yahoo.com.

\section{REFERENCES}

1. Sadanadan $R$ et al., 2018. Towards global health security: response to the may 2018 Nipah virus outbreak linked to Pteropus bats in Kerala, India. BMJ Glob Health 3: e001086.

2. Chattu VK, Kumar R, Kumary S, Kajal F, David JK, 2018. Nipah virus epidemic in southern India and emphasizing "one health" approach to ensure global health security. J Fam Med Prim Care 7: 275-283.

3. Ajith Kumar AK, Anoop Kumar AS, 2018. Deadly Nipah outbreak in Kerala: lessons learned for the future. Indian J Crit Care Med 22: 475-476.

4. Arunkumar G, Chandni R, Mourya DT, Singh SK, Sadanandan R, Sudan P, Bhargava B, Nipah Investigators People and Health Study Group, 2019. Outbreak investigation of Nipah virus disease in Kerala, India, 2018. J Infect Dis 219: 1867-1878.

5. Kumar CPG et al., 2019. Infections among contacts of patients with Nipah virus, India. Emerg Infect Dis 25: 1007-1010.

6. WHO, 2019. Effective Containment of the Nipah Virus Outbreak in India Highlights the Importance of a Strong Health System. Geneva, Switzerland: World Health Organization. Available at: http://www.who.int/csr/disease/nipah/effective-containmentin-india/en/. Accessed December 21, 2019.

7. Shultz JM et al., 2016. The role of fear-related behaviors in the 2013-2016 west Africa Ebola virus disease outbreak. Curr Psychiatry Rep 18: 104.

8. Gray N, Stringer B, Bark G, Heller Perache A, Jephcott F, Broeder R, Kremer R, Jimissa AS, Samba TT, 2018. "When Ebola enters a home, a family, a community": a qualitative study of population perspectives on Ebola control measures in rural and urban areas of Sierra Leone. PLoS Negl Trop Dis 12: e0006461.

9. Sazzad HM et al., 2103. Nipah virus infection outbreak with nosocomial and corpse-to-human transmission, Bangladesh. Emerg Infect Dis 19: 210-217.

10. Bloom DE, Cadarette D, Sevilla JP, 2018. The economic risks and impacts of epidemics. Finance Dev 55: 46-49.

11. Kerala Municipality Act 1994. Available at: http://sanitation.kerala. gov.in/wp-content/uploads/2017/07/kerala_-municipality_act_1994.pdf. Accessed May 5, 2020.

12. McEwen BS, 2007. Physiology and neurobiology of stress and adaptation: central role of the brain. Physiol Rev 87: 873-904.

13. Doedeh J, 2017. Rapid field response to a cluster of illnesses and deaths-Sinoe county, Liberia, April-may, 2017. Morb Mortal Wkly Rep 66: 1140-1143.

14. Victory KR, Coronado F, Ifono SO, Soropogui T, Dahl BA, 2015. Ebola transmission linked to a single traditional 
funeral ceremony-Kissidougou, Guinea, December, 2014-January 2015. Morb Mortal Wkly Rep 64: 386-388.

15. Merler S, Ajelli M, Fumanelli L, Gomes MFC, Piontti APY, Rossi L, Chao DL, Longini IM Jr., Halloran ME, Vespignani A, 2015. Spatiotemporal spread of the 2014 outbreak of Ebola virus disease in Liberia and the effectiveness of non-pharmaceutical interventions: a computational modelling analysis. Lancet Infect Dis 15: 204-211.

16. Chakraborty A et al., 2016. Evolving epidemiology of Nipah virus infection in Bangladesh: evidence from outbreaks during 2010-2011. Epidemiol Infect 144: 371-380.

17. Manguvo A, Mafuvadze B, 2015. The impact of traditional and religious practices on the spread of Ebola in west Africa: time for a strategic shift. Pan Afr Med J 22 (Suppl 1): 9.

18. Parveen S, Islam MS, Begum M, Alam M-U, Sazzad HMS, Sultana R, Rahman M, Gurley ES, Hossain MJ, Luby SP, 2016. It's not only what you say, it's also how you say it: communicating Nipah virus prevention messages during an outbreak in Bangladesh. BMC Public Health 16: 726.

19. Laungani DP, 2001. Hindu deaths in India-Part 1. Int J Health Promot Educ 39: 88-96.

20. Poyil M, 2019. Homage to the Departed: A Study of Funeral Customs Among the Tribes in Malabar, Kerala, Other BooksAcademia.edu. Available at: https://www.academia.edu/28657612/ Homage_to_the_Departed_A_Study_of_Funeral_Customs_
Among_the_Tribes_in_Malabar_Kerala. Accessed December 21, 2019.

21. Le AB, Witter L, Herstein JJ, Jelden KC, Beam EL, Gibbs SG, Lowe JJ, 2017. A gap analysis of the United States death care sector to determine training and education needs pertaining to highly infectious disease mitigation and management. $J$ Occup Environ Hyg 14: 674-680.

22. Davidson S, Benjamin W, 2007. Risk of infection and tracking of work-related infectious diseases in the funeral industry. Am $J$ Infect Control 34: 655-660.

23. Ringane A, Milovanovic M, Maphakula D, Makete F, Omar T, Martinson N, 2019. An observational study of safe and risky practices in funeral homes in South Africa. S Afr Med J 109: 587-591.

24. World Health Organization, 2014. hs-meeting.pdf. Available at: https://www.who.int/csr/resources/publications/ebola/hs-meeting. pdf?ua=1. Accessed December 22, 2019.

25. Spengler JR, Ervin E, Towner JS, Rollin PE, Nichol ST, 2016. Perspectives on west Africa Ebola virus disease outbreak, 2013-2016. Emerg Infect Dis 22: 956-963.

26. WHO Ebola Response Team, 2016. After Ebola in west Africa - unpredictable risks, preventable epidemics. $N$ Engl J Med 375: 587-596.

27. Kieny MP, Dovlo D, 2015. Beyond Ebola: a new agenda for resilient health systems. Lancet 385: 91-92. 